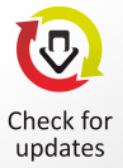

updates

\title{
Coercive Authority and Trust in Tax Authority in Influencing Voluntary Tax Compliance: A Study of Slippery Slope
}

\author{
Uswatun Khasanah*, Sutrisno T., Endang Mardiati
}

\section{OP OPE}

Department of Accounting, Universitas Brawijaya, Jalan Veteran, Ketawanggede, Lowokwaru, Kota Malang, East Java 65145, Indonesia. *Correspondence:@ uswatunkatasmir@gmail.com This article is avalilable in: http://journal.umy.ac.id/index.php/ai DOI: 10.18196/jai.2001109

\section{Citation:}

Khasanah, U., Sutrisno, T., \& Mardiati, E. (2019). Coercive Authority and Trust in Tax Authority in Influencing Voluntary Tax Compliance: A Study of Slippery Slope. Journal of Accounting and Investment, 20(1), 75-93.

Received:

10 September 2018

Reviewed:

16 September 2018

Revised:

18 September 2018

Accepted:

04 October 2018

Copyright: (C) 2019

Khasanah, Sutrisno \&

Mardiati. This is an open access article distributed under the terms of the

Creative Commons Attribution License, which permits unrestricted use, distribution, and reproduction in any medium, provided the original author and source are credited.
ABSTRACT: The improvement of tax compliance in Indonesia has not resulted in increase of tax ratio of the same year. From this perspective, the researchers conducted a study on voluntary tax compliance using theory of slippery slope. This study aims to provide an empirical evidence on the potential influence of tax audits, tax rewards, and trust in tax authority towards voluntary tax compliance. The study was conducted on Corporate Taxpayers who were registered as PKP (Taxable Enterprise). Structural Equation Modeling-Partial Least Square (SEM-PLS) was employed as the analytical tool in the study. Our empirical findings show that tax audits could influence voluntary tax compliance and trust in tax authority was proven successful to reduce the influence of tax audit towards voluntary tax compliance. However, other findings also show that rewards were not proven successful in influencing voluntary tax compliance.

KEYWORDS: voluntary tax compliance; slippery slope; coercive power; trust

\section{Introduction}

In 2015, Indonesian Tax Authority started to show activities in educating and disseminating information to its citizens to pay their taxes. One activity that attracted most public's interest was tax amnesty. Tax amnesty is implemented to meet the target of the Directorate General of Taxation (DGT) i.e. contribute of over $70 \%$ in State Budget (Directorate General of Taxation, 2016). As such, such target indicated that tax started to become the main pillar of state revenue.

There are a lot of studies on tax compliance. Tax compliance is still an issue in Indonesia, in that Indonesia was ranked eighth in ASEAN in 2017 and 126th in the world in tax compliance. There are studies conducted by OECD (2016), World Bank (2015), World Bank (2016 \& 2017) regarding tax compliance in several countries in the world (Table 1). While Indonesia's tax compliance has improved since 2015, its tax ratio however shows a decline in the pertaining year. Table 2 shows that Indonesia's tax ratio experienced a decrease by $0.40 \%$ indicating that Indonesia's Gross Domestic Product (GDP) experienced an increase that was not proportional to the increase in tax payment.

The above tax ratio shows that improvement in tax compliance and tax amnesty performance applied bylndonesian government has yet been successful in meeting the target of tax increase. Since 2015, Indonesian government has strived to improve its tax compliance by drawing up strategic plans 2015-2019. The current phenomenon suggests that tax compliance has been increasing every year, its tax revenue however shows 
Table 1 Ranking of State Tax Compliance across Southeast Asian countries

\begin{tabular}{clcccccc}
\multirow{2}{*}{ No. } & \multirow{2}{*}{ Country } & \multicolumn{2}{c}{2015} & \multicolumn{2}{c}{ 2016 } & \multicolumn{2}{c}{2017} \\
\hline 1 & Singapura & 97.19 & 5 & 96.56 & 5 & 97.99 & 5 \\
2 & Brunei D. & 84.40 & 30 & 89.61 & 16 & 91.36 & 16 \\
3 & Malaysia & 83.95 & 32 & 84.31 & 31 & 84.16 & 34 \\
4 & Thailand & 77.90 & 62 & 77.70 & 70 & 75.80 & 81 \\
5 & Kamboja & 73.06 & 90 & 73.06 & 93 & 73.06 & 97 \\
6 & Filipina & 66.46 & 127 & 66.23 & 126 & 71.06 & 110 \\
7 & Myanmar & 68.64 & 116 & 74.80 & 84 & 70.03 & 112 \\
8 & Indonesia & 53.66 & 160 & 60.46 & 148 & 66.83 & 126 \\
9 & Laos & 66.10 & 129 & 66.10 & 127 & 66.06 & 129 \\
\hline
\end{tabular}

Note: $\mathrm{TC}=$ Tax Compliance, Rank $=$ World Ranking of Tax Compliance

Source: The World Bank

that it has yet to catch up with the increase in GDP resulting in a decrease in the tax ratio.

The government puts a major concern on the strategy to increase tax compliance and tax ratio as tax is the central pillar of state revenue. The need to increase tax revenue has forced the government to pay more attention to issues that influence the increase in tax compliance and tax ratio. The rules and behavior of tax authorities are some of the issues that may influence tax compliance (Ratmono \& Cahyonowati, 2013). On the other hand, increasing voluntary tax compliance may lead to an increase in state tax ratio (Gangl, Hofmann \& Kirchler, 2015; Kirchler, Hoelzl \& Wahl, 2008). Kirchler et al. (2008) further explained that voluntary tax compliance could sustain tax compliance for longer period. The reason is that voluntary tax compliance tends to be compliant due to a high level of trust in tax and government authorities so that tax compliance may be maintained for a longer period. (Gangl et al., 2015; Kirchler et al., 2008).

Tax audit is selected as one variable because previous studies of both of these variables showed inconsistent results. Finding from a study conducted by Slemrod, Blumenthal and Christian (2001) using close examination indicates that close examination could increase tax compliance only to low to medium taxpayers but it reduced tax compliance to large taxpayers.

Table 2 Tax Ratio across Southeast Asia countries

\begin{tabular}{lcc}
\hline \multirow{2}{*}{ Country } & \multicolumn{2}{c}{ Year } \\
\hline Singapura & 13.60 & $\mathbf{2 0 1 6}(\boldsymbol{\%})$ \\
Malaysia & 15.30 & 14.30 \\
Thailand & 16.50 & 15.70 \\
Kamboja & 14.20 & 15.30 \\
Filipina & 13.00 & 13.70 \\
Myanmar & 6.00 & 6.40 \\
Indonesia & 10.70 & 10.30 \\
\hline
\end{tabular}

Source: The World Bank 
Reward is selected as a variable of coercive authority as the researchers would like to analyze the extent to which the tax authority in Indonesia values its taxpayers who contributed part of their income for tax. A study by Mahadianto and Astuti (2017) using privileged tax and testing the tax compliance found that privileged tax could increase tax compliance. The theory of slippery slope presents an argument from consequences traditionally conceptualized as an informal fallacy, Kirchler et al. (2008) speculated on the dynamic relationship between authority and trust but they had not provided further explanation on the potential interaction between authority and trust. Afterwards, Gangl et al. (2015) explained the possibility that interaction between authorities and trust could weaken and strengthen each other at a certain level.

This study is a modification of a study by Gangl et al. (2015) by way of reducing the dependent variable to only voluntary tax compliance. Such reduction was taken because the researchers wanted to focus on voluntary tax compliance which is more consistent in complying. In addition, based on the researchers' knowledge, that there have not been many studies on voluntary tax compliance, especially in Indonesia. This study also details the independent variables as in Gangl et al. (2015), using coercive authority variable as a tax audit variable and a negative coercive authority, and using reward as a positive coercive authority variable.

The development of theory on voluntary tax compliance in Slippery Slope may promote a new way of increasing tax compliance in Indonesia. Therefore, the researchers are motivated to conduct a study on voluntary tax compliance to provide a solution for the government in increasing voluntary tax compliance and tax ratio within the same period of time. Based on the above explanation, this study aims to provide empirical evidence regarding the influence of potential tax audit and tax reward on voluntary tax compliance. In addition, this study also provides empirical evidence on the influence of trust in tax authority as a moderating variable between variables of tax audits possibility on voluntary tax compliance.

Findings of this study indicate that the potential tax audit may increase voluntary tax compliance. On the other hand, tax rewards presents a different result in which it actually reduced voluntary tax compliance. Results from moderation test showed that tax trust could reduce the influence of potential tax audits in influencing voluntary tax compliance. This study can provide input for the government as the government needs to increase voluntary tax compliance. In the theory of slippery slope, it is explained that increasing voluntary tax compliance can both improve tax compliance and tax ratios. Therefore, this study may serve as a solution for the government to increase tax ratio.

\section{Literature Review and Hypotheses Development}

\section{Theory of Slippery Slope}

Issues of tax compliance raise various theories expected to become the solutions to increase state tax revenue. The emergence of theory of slippery 
slope was motivated that tax compliance is not only about economic factors, but it is also social psychological factors. Kirchler et al. (2008) created a theoretical framework for slippery slope with two big dimensions, namely the power controlled by the tax authority and the trust of taxpayer on tax authority. The power controlled by tax authority is thought to have the capacity of improving tax compliance when viewed from an economic paradigm, it will improve tax compliance with force.

The theory describes tax compliance by combining economic variables with social psychology variables. Previous studies on tax compliance tended to use economic variables (Kirchler et al., 2008), whereas its development also include psychological variables that influence tax compliance (Kirchler et al., 2008). Kirchler et al. (2008) explained that voluntary tax compliance is influenced by two factors, namely economic factors and psychological factors. Economic factors are related to the authorization controlled by the tax authority, while psychological factors are related to the trust of the taxpayers. Other authorization controlled by the tax authority is the legitimate authorization. This authorization is intended to compel the public become active in supporting authority's policies (Tyler, 2006; Tyler, 2010).

Coercive authority in Gangl et al. (2015) consists of negative coercive authority i.e. tax audit and positive coercive authority i.e. reward given to taxpayers. The authors stated that tax audit was considered as negative coercive authority because it indicated authority's distrust towards taxpayers. Reward is a positive coercive authority. The authors stated that reward is a positive coercive authority because the authority respects taxpayers who were compliant.

Kirchler et al. (2008) explained that trust in tax authority is a psychological variable that not only it is able to improve tax compliance, but also to maintain tax compliance. They also stated that it is likely that the dimension of power and trust has a dynamic relationship but they did not provide explanations on the interaction between strength and trust.

\section{Theory of Bureaucratic Reform}

The theory of bureaucratic reform describes systematic, integrated and comprehensive efforts to create good governance. Etymologically, bureaucracy consists of Bureau and cracy. The word 'bureau' originated from French which means a writing desk or a place where officials work, while 'cracy' originated from a decline of Greek i.e. to regulate (Albrow, 1970). Good governance enables state governance mechanism to maintain a constructive synergy between the government, private sector, and community effectively and efficiently (Sedarmayanti, 2010).

The Directorate General of Taxation (2015) explained that the government was to implement bureaucratic reform in taxation with targets and activities set in detail every year from one stage to the next. Henceforth, this reform was used to improve tax compliance implemented by the government for the next five years. The objective of bureaucratic reform was set to create a good governance. Based on a Decree of State Minister for State-Owned Enterprises No. EP-117/M-MBU/2002 (Negara, 2002) regarding implementtation of good governance practices in SOE, there is a set of good 
governance principle which consists of five aspects, namely transparency, independence, accountability, responsibility, and fairness.

Tax bureaucratic reform aims to create a clearer tax structure in carrying out functions of delegation and supervision as well as to produce tax service that are fast, accurate, fair, consistent and transparent. Bureaucratic reform is also intended to improve the compliance, awareness and participation of taxpayers within the taxation system to facilitate an increase in state tax revenue (Puspita, Subroto, \& Baridwan, 2016).

\section{The Influence of Potential Tax Audit on Voluntary Tax Compliance}

Tax audit is one of the coercive authority variables of tax authority. The theory of slippery slope explains that voluntary tax compliance is influenced by authorization (coercive and legitimacy) which is controlled by the tax authority (Kirchler et al., 2008). Coercive authorization is the authorization controlled by the tax authority to force taxpayers to comply with tax regulation. Tax audit is a deterrence factor which is part of a coercive authorization that is negative. Negative coercive power indicates that there is a distrust of authority towards taxpayers therefore the taxpayers need to be audited (Gangl et al., 2015).

Tax audit is also related to theory of bureaucracy reform. Theory of bureaucracy reform explains that there are systematic, integrated and comprehensive efforts to create good governance. Good governance enables state governance mechanism to maintain a constructive synergy between government, private sector, and community effectively and efficiently (Sedarmayanti, 2010). Based on the DGT's Performance Report 2015, the Indonesian government through Ministry of Finance presented a plan to carry out reforms in taxation. Tax audit is certainly one part of the tax reform to make tax audit more effective, efficient, and on target. This topic has attracted researchers to conduct a study related to the potential tax audit in Indonesia in influencing voluntary tax compliance in Indonesia.

As described in Gangl et al. (2015), potential tax audit may influence voluntary tax compliance because taxpayers tend to choose to comply rather than be proven to report taxation not-in-accordance and therefore must take a legal action. The potential tax audit may improve tax compliance described in an article by Mendoza, Wielhouwer, and Kirchler, (2017) who conducted a study that divided audit levels on a certain scale. The study showed that tax audits could increase tax compliance only to a certain level. The leveling is related to an inspection level in finding tax fraud in accordance with the taxation regulation in Austria. A study by Konrad, Lohse, and Qari (2016) of tax audits that divided face to face and not showed any results that tax compliance could increase by $80 \%$ with the possibility of face to face audit by the tax authority. Based on the argument in the theory of slippery slope and supported by the theory of corruption reform, it can be concluded that the potential tax audit may influence voluntary tax compliance if the inspection is carried out effectively, efficiently and on target. Therefore, the researchers state a hypothesis as follows:

$H_{1}$ : Potential tax audit has a positive influence on voluntary tax compliance. 


\section{The Influence of Reward on Voluntary Tax Compliance}

Reward is one of coercive authority variables in the theory of slippery slope. As previously explained, the theory describes voluntary tax compliance influenced by the authorization controlled by the tax authority (Kirchler et al., 2008). Reward is part of the coercive authority which is positive because reward indicates that there is trust in authority towards taxpayers so that the taxpayers need to be rewarded for their previously compliancy with the tax (Gangl et al., 2015). The theory also explains that reward may improve the quality of relationship between the authority and taxpayers as taxpayers feel appreciated by the tax authority.

Reward may be conducted in various forms and ways, depending on rules and creativity of authority of a country and a region. A reward may be given in the form of lottery prizes to compliant taxpayers, it can also provide privilege (privileges given with certain conditions) for compliancy, etc. Reward given as lottery prize may increase tax compliance if the chance to win such prizes falls around one to twenty-five (Alm, McClelland, \& Schulze, 1992). However, the effect is still unknown for less chances. Other study was carried out by providing information on the use of tax fund in every government activity or tax authority. Such activities may also improve tax compliance (Lamberton, De Neve, \& Norton, 2013). In their article, Gangl et al. (2015) explained that rewards may influence voluntary tax compliance.

Indonesian Minister of Finance No. 74/PMK.03/2012 (Finance, 2012) regulates taxpayers with certain criteria i.e. the right to receive an overpayment introduction. This regulation also sets the requirements to obtain these criteria to comply with the tax regulations for at least 3 consecutive years and must be certified through a tax audit. This demonstrates that Indonesian government appreciates its compliant taxpayers by providing rewards in the form of pre -payment facilities to facilitate the return of excess tax payment. A study conducted by Mahadianto and Astuti (2017) tested a privileged tax on tax compliance using taxpayers within Pratama Tax Service Office (KPP) region in Cirebon city. The study found that privileged tax could increase tax compliance. Based on the argument of the slippery slope theory, it can be concluded that rewards in the form of pre-payment and lottery prize could influence voluntary tax compliance. Therefore, the study formulates a hypothesis as follows:

$\mathrm{H}_{2}$ : Reward has positive influence on voluntary tax compliance.

\section{The impact of trust in tax authority on the influence of potential tax audit and fair tax procedure on voluntary tax compliance}

Trust in tax authority and potential tax audits carry a dynamic relationship and can influence each other. In the conceptualization of theory of slippery slope, Kirchler et al. (2008) tried to speculate on the dynamic relationship between tax authority and trust but the study has not provided further explanation on the interactions that occurred between the authority and trust. 
Trust is a psychological influence of taxpayers on tax authority, therefore if taxpayer believes in the tax authority, the community will indirectly and without difficulty comply with the tax authority. Gangl et al. (2015) stated that trust is important in social life and there is a broad agreement that trust is the willingness of individuals or groups to take a risk. The trust of taxpayers plays an important role in influencing the potential tax audit. Further, Gangl et al. (2015) explained the possibility of interaction between authorization and trust can weaken and strengthen reciprocally at a certain level.

Gangl et al., (2015) also explained that the authorization represented by the possible tax audits could increase its influence on voluntary tax compliance with the trust of high taxpayers. Taxpayers need not be afraid to be examined or found payment errors and tax reporting because taxpayers have a trust in the tax authority, and can apply otherwise. A study by Ratmono and Cahyonowati (2013) elucidated that trust was yet to influence the interaction between potential tax audits on tax compliance. Ratmono and Cahyonowati (2013) explained that the trust level of taxpayers in Indonesia was still low therefore trust in tax authority could not influence tax audits and voluntary tax compliance.

Gangl et al. (2015) indicated that trust in tax authority may have an influence on taxpayer's decision related to potential tax audit. The data on voluntary tax compliance is still limited if it is related to potential tax audits and tax trust, so the researchers wanted to provide evidence in this study that the influence of trust in tax authority may have an effect (increase or decrease) on the interaction between potential tax audits of voluntary tax compliance. Based on the argument of the above slippery slope theory, it can be concluded that trust in tax authority can moderate the effect of potential tax audit and fairness of tax procedure on voluntary tax compliance. Therefore, this study formulates a hypothesis as follows:

$H_{3}:$ Trust in tax authority moderates the effect of potential tax audit towards voluntary tax compliance.

\section{Research Method}

This study aims to examine factors that influence voluntary tax compliance. As such, this study is categorized as a causal study (Now \& Bougie, 2013). The study was conducted in Indonesian Directorate General of Taxation which oversees the agency on taxation in Indonesia. Indonesia was chosen because the realization of its tax compliance has been improved but its tax ratio has been decreased in the last two years.

Sample of the study is Corporate Taxpayers that have obtained the criteria for Taxable Entrepreneurs (PKP). This sampling was chosen because only PKP Taxpayer Agency that have reached a turnover of >IDR4.8 billion, and is obligated to provide periodic financial reports and tax audit conducted in accordance with the financial report audit procedures (Directorate General of Taxation, 2013). The researchers submitted a research permit to several 
KPPs in the Malang region, but we only received a reply from Kepanjen Tax Office for a permission to conduct a study on taxpayers in the KPP area.

Data collected in this study is primary i.e. the perception of taxpayers in the Regional Tax Office of Third Tax Office in East Java. The objective is to find out factors influencing taxpayers to become voluntary taxpayers. The data was collected using a questionnaire which consisted of research items (Brockmann, Genschel, \& Seelkopf, 2016; Kastlunger, Lozza, Kirchler, \& Schabmann, 2013; Kirchler et al., 2008).

The variables observed in this study are variables related to the theory of slippery slope and theory of bureaucratic reform. They are consisted of 3 variables, namely; independent variables, dependent variables, and moderating variables. The measurement of each variable employs a 7-point likert scale as this type of scale may be better received by respondents and has fairly good criteria in terms of validity, reliability of discrimination ability and stability (Budjiji, 2013). These seven likert scales are (1) Strongly Disagree (STS), (2) Disagree (TS), (3) Somewhat Disagree (ATS), (4) Neutral (N), (5) Somewhat Agree (US), (6) Agree (S) and (7) Strongly Agree (SS).

\section{Operational Definition of Variables}

Potential tax audit is a potential audit carried out by the tax authority on taxpayers to ensure that the tax paid is in accordance with the actual tax that must be paid. The audit is coded with AP. This study used the instruments used in previous studies namely Kastlunger et al. (2013). Rewards tax is something that the authority gives to taxpayers as a reward because taxpayers have complied with the tax regulations. This reward can be in the form of information on the use of brand tax revenue. The audit is coded with RP. This study used the instruments from several previous studies namely Brockmann et al. (2016). Trust in tax authority is a psychological factor in taxpayers influenced by various factors to ensure that the tax authority shall use the tax paid properly according to what the taxpayers expected. It is coded with TO. This study used the instruments from several previous studies namely Kastlunger et al. (2013). Voluntary tax compliance is the behavior of taxpayers who were willing to fulfill their tax obligations in the form of counting, depositing, and reporting their tax to the tax authority voluntarily. It is coded with VTC. This study used the instruments from several previous studies namely Kirchler et al. (2008).

\section{Method of Data Analysis}

Method of data analysis used to test the hypotheses is Structural equation modeling - Partial Least Square (SEM-PLS) and the study used Warp PLS version 6.0. The use of PLS compared to other statistical analysis tools in research is based on the type of study which is either to test or to develop a theory. According to Hair, Hult, Ringle, and Sarstedt (2016) the use of SEMPLS is more suitable for a study whose objective is to explain and predict a construct in research. This study strives to explore the theory of slippery slope by making the trust in authority as a moderating variable, therefore SEM-PLS is more suitable as a statistical analysis tool in this study. 
Table 3 Type of Moderation Variable

\begin{tabular}{ll}
\hline Type of Moderation Variable & \multicolumn{1}{c}{ Definition } \\
\hline Quasi & There is influence on the main effect \\
Predictor & There is interaction with the moderating effect \\
& There is influence on the main effect \\
Pure & There is no interaction on the moderation effect \\
& There is no influence on the main effect \\
Homologizer & There is interaction with the moderating effect \\
& There is no influence on the main effect \\
& There is no interaction on the moderation effect
\end{tabular}

\section{Hypotheses Testing}

Testing the hypotheses $\mathrm{H}_{1}$ to $\mathrm{H}_{3}$ is done using PLS. Testing $\mathrm{H}_{1}$ to $\mathrm{H}_{2}$ is testing the direct effect without moderation, while testing $\mathrm{H}_{3}$ is a test of the moderating effect. This moderation test uses Moderated Regression Analysis (MRA) using PLS testing tools (There are moderation provisions that might later be formed in this study, so that even if there is no significant influence testing the moderation effect will still be done. This study refers to the research article Sugiono (2004) to identify the types of moderating variables, shown in Table 3.

This moderation test was carried out in two stages, namely testing before and after moderation. The test is illustrated in the following three formulas:

1) $\eta=\gamma 1 \xi 5+\zeta 1$ (influence on the main effect)

2) $\eta=\gamma 1 \xi 1 * \xi 5+\zeta 1$ (influence on the interaction of moderating effects)

Next, the researchers identify moderating variable based on the criteria in table 3. Testing the hypotheses was conducted in the following methods:

1) Determining the level of significance or critical value $(\alpha)$ i.e. equal to $5 \%$.

2) Comparing the significance of $p$ value and coefficient direction. If the significance of $p$ value $\leq 0.05(5 \%)$ and the coefficient direction is in accordance with the direction specified in the hypotheses, the hypotheses are accepted, otherwise the hypotheses are rejected.

\section{Result and Discussion}

This study uses owner/persons in charge of taxation in companies that have a turnover of more than IDR4.8 billion per year as its respondents. The selection of respondents was chosen because the owner/persons in charge of taxation is part of the decision maker who influence the culture of tax compliance in a company. The owner/persons in charge of taxation can determine whether or not to comply with the tax regulation.

The researcher distributed the questionnaire at KPP for ten days before June 30, 2018. This is done because the Corporate Tax Objects submits their Tax Return (SPT) of Value Added Tax (PPN) and Article 23 Income Tax near the 
$30^{\text {th }}$ of every month. The respondents who came to submit SPT on the day of the study were given a questionnaire in paper form and a link to fill out online questionnaire. The selection of respondents who came to submit this SPT was considered efficient because there was a 2017 Circular which explained that the fulfillment of tax obligations could only be done by the person in charge of the Corporate Taxpayer and/or the taxpayer's representative. Representative of the taxpayer is the person in charge who receives or is given the authority the by the taxpayer to be responsible and participates in the decision-making related to taxation as evidenced by power of attorney signed by the Corporate Taxpayer, or in such case, the director or owner of the Business Entity.

Questionnaires were distributed in KPPs who were gave the study permission to contact and use their taxpayers as respondents. The researchers and fellow researchers distribute to the taxpayers who came to filled out the questionnaires during office hours. In addition, the researchers also use friendship networking to help find potential respondents. Friends of the researchers who work as accountants and in taxation office within Malang region were also asked to help filling out and distributing questionnaires to offices where their colleagues worked in offices that fit in the requirements of this study.

The distributed questionnaires were divided into two forms, namely hard copy and online questionnaire. The division served to facilitate the respondents in filling out and collecting the data. Online questionnaires were provided by the researchers using Google docs facility. The total questionnaire distributed to KPP was 311 questionnaires. The distributed questionnaire is illustrated in table 4 . Table 4 shows that the response rate of this study is $88.42 \%$. We achieved good response rates because the researchers conducted approaches to research respondents who came to KPP and established good communication with KPP especially those in the front office area to help accelerate questionnaires distribution.

Table 4 shows that there are unreturned 36 questionnaires. There are 11 questionnaires that cannot be used because there are several unanswered questions and invalid answers (for example: the respondent answered 1 from the beginning to the end of the question). There were 91 questionnaires that did not meet the requirements because the researchers conducted research on corporate taxpayers who had been confirmed as PKP (taxable enterprise) and were still active as PKP. These corporate taxpayers who filled out the questionnaire were out of these conditions, the questionnaire could not be used in this study. Table 5 shows the general description of the demographic characteristics of the respondents.

Table 4 Sample Distribution and Returned Questionnaire

\begin{tabular}{lc}
\multicolumn{1}{c}{ Description } & Total \\
\hline Questionnaires distributed offline & 168 \\
Questionnaires distributed Online & 143 \\
Unanswered questionnaires & $(36)$ \\
Questionnaire that cannot be Led & $(11)$ \\
Questionnaires that do not meet the requirements & $(91)$ \\
Total questionnaire used in the Study & 173 \\
\hline
\end{tabular}


Table 5 Respondents' Demographic Characteristics

\begin{tabular}{clcc}
\hline No. & Category & Number of Respondent & $\%$ \\
\hline 1 & Men & 58 & 33.52 \\
\hline 2 & Women & 106 & 61.27 \\
3 & blank & 9 & $5, .21$ \\
& Total & 173 & 100 \\
1 & $<20$ years old & 0 & \\
2 & $21-30$ years old & 68 & 39.32 \\
3 & $31-40$ years old & 74 & 63.24 \\
4 & $41-50$ years old & 29 & 16.76 \\
5 & $>50$ years old & 2 & 1.16 \\
6 & blank & 9 & 5.2 \\
& Total & 173 & 100 \\
\hline 1 & Owner & 34 & 19.65 \\
\hline 2 & Employee & 118 & 68.21 \\
3 & Tax consultant & 12 & 6.93 \\
4 & blank & 9 & 5.2 \\
& Total & 173 & 100 \\
1 & Brevet certified & 128 & 73.98 \\
\hline 2 & Non-Brevet certified & 36 & 20.81 \\
\hline 3 & blank & 9 & 5.2 \\
& Total & 173 & 100 \\
\hline
\end{tabular}

As shown in Table 5, the number of female respondents is higher than that of men, and there are 9 respondents who did not fill in their gender information. The number indicates that there are still more women working within taxation sector. This difference will not have much effect on this study because the study focuses on voluntary compliance of corporate taxpayers.

Based on Table 5, majority of our respondents were between 31-40 years old. We believe this is related to tax regulation in that it require only taxpayers or representative of taxpayers should manage the tax obligations. So only financial managers or people or employees in equivalent position who gained the trust from the taxpayers who reported their tax to KPP in accordance with the conditions set by the Directorate General of Taxation.

Table 5 shows that only $6.93 \%$ of company owners carry out their own tax obligations to KPP. In addition, the majority of respondents who filled out the questionnaire were company employees. In accordance with Circular Letter No. SE/02.PJ/2017, employees who are allowed to carry out tax obligation are employees who already have a Special Power of Attorney from the Agency/Company, have worked more than 1 year (in the company), have taken taxation education namely brevet tax at least $A$, and become representatives companies in fulfilling tax obligations.

Table 5 shows that $73.98 \%$ of respondents have taken tax education in the form of tax brevet. This is also related to the previous explanation about Circular Letter No. SE/02.PJ/2017 which requires employees appointed as the entity Taxpayers' representatives to fulfill out tax obligations, must have taken brevet tax education proven by showing tax brevet certificates. 
Table 6 Descriptive Statistics of Research Variables

\begin{tabular}{clcccc}
\hline No. & \multicolumn{1}{c}{ Variable } & Minimum & Maximum & (mean) & Standard Deviation \\
\hline 1 & Audit probability & 1 & 7 & 5.115 & 1.019 \\
2 & Tax Rewards & 1 & 7 & 3.412 & 0.917 \\
3 & Trust & 1 & 7 & 4.533 & 1.074 \\
4 & Voluntary tax compliance & 1 & 7 & 5.127 & 0.941 \\
\hline
\end{tabular}

The frequency of the answer values in each variable, mean value, and standard deviation are used as the basis for interpreting the responses of respondents. The value used in answering one variable consists of positive statements. Table 6 shows that all constructs had a minimum and maximum value of 1 and 7 . The average value indicates that the respondent's answer of average potential tax audit is 5.115. Based on the indicator, this result indicates that the potential tax audit is quite high. In contrary, the average value of tax rewards i.e. 3.412, meaning that the respondents believed that the tax rewards was quite low. Finding from standard deviation shown falls in the range between maximum and minimum values, and the standard deviation value also does not exceed the average value of the study. This shows that the answers given by the respondents to a statement did not have a big difference. That is, the answers of each respondent tend to be consistent so that they can represent the entire data used in this study.

\section{Hypotheses Testing}

To test the hypotheses, the researcher used the PLS Regression WarpPLS 6.0 algorithm with stable resampling method 3 . The researchers chose stable 3 because the resampling method produces an estimated standard errors (Kock, 2015) and $p$ value (Kock, 2015) with the best precision compared to other resampling method. Testing the hypotheses in this study is divided into two stages, namely the stage of testing the hypotheses before moderation and after the moderating effect.

All tests in the study used one-tailed hypotheses. The testing used $p$ values because WarpPLS 6.0 is a statistical tool that produces one-tailed $p$ values (Kock, 2015). The testing of hypotheses with moderating effects did not use direction (two-tailed consequences) so that the $p$ value will be multiplied by two (Kock, 2015). Testing the $p$ value is determined, if the significance of $p<0.05$, the hypothesis is accepted, and if the value of $p>0.05$, the hypothesis is rejected. The results of hypotheses testing before modification are presented in table 7.

A results of hypotheses testing is shown in table 7. One hypothesis is accepted i.e. $\mathrm{H}_{1}$ because it has the direction in accordance with the hypothesis (for variables with direction of research) and the $p$-value that is

Table 7 Hypotheses Test Results

\begin{tabular}{ccccc}
\hline Hypotheses & information & Coefficient value & P value & Conclusion \\
\hline $\mathrm{H}_{1}$ & $\mathrm{AP} \rightarrow$ VTC & 0.159 & $0.016^{*}$ & Accepted \\
$\mathrm{H}_{2}$ & $\mathrm{RP} \rightarrow$ VTC & -0.188 & $0.066^{*}$ & Refuted \\
$\mathrm{H}_{3}$ & $\mathrm{AP} *$ TO $\rightarrow$ VTC & -0.277 & $<0.001^{* *}$ & Accepted \\
\hline
\end{tabular}

$*$ = one-tailed ${ }^{* *}=$ two-tailed 
Table 8 Types of moderation effects

\begin{tabular}{|c|c|c|c|c|}
\hline \multicolumn{2}{|c|}{ Influence on main effect } & \multicolumn{2}{|c|}{ Influence on moderation effect } & \multirow{2}{*}{ Conclusion } \\
\hline Information & $P$ value & Information & $P$ value & \\
\hline \multirow{2}{*}{$\mathrm{TO} \rightarrow \mathrm{VTC}$} & \multirow{2}{*}{$0.006 * *$} & $\mathrm{AP}^{*} \mathrm{TO} \rightarrow \mathrm{VTC}$ & $<0.001^{* *}$ & Quasi \\
\hline & & $\mathrm{KP} * \mathrm{TO} \rightarrow \mathrm{VTC}$ & $0.016 * *$ & Quasi \\
\hline
\end{tabular}

significantly below 0.05 . Table 7 also shows that two moderation interactions are accepted, namely $\mathrm{H}_{3}$ with the possibility of tax audit and tax trust (AP*TO) because the $p$-value is significantly below 0.05 . The hypotheses used testing without direction or two-tailed therefore the direction of coefficient value does not serves as a requisite for accepting the hypotheses.

Other researcher tested the influence of moderating variables, i.e. the trust on tax authority on voluntary tax compliance to determine whether or not there was an influence on the main effect (moderating variable towards endogenous variables). Table 8 presents several types of moderating variables from an empirical testing. The determination of this type of moderation was based on the previous explanation.

After conducting several stages of hypotheses testing, namely testing before moderation, testing the moderation interaction, and testing the main effects, the results of the study are illustrated in Figure 1.

\section{The Influence of Potential Tax Audit on Voluntary Tax Compliance}

The results of this study provide empirical evidence that the potential tax audit has a significant influence on voluntary tax compliance. The coefficient value in this study shows positive value, which means that the higher the possibility of tax audit is, therefore the higher the voluntary tax compliance is. The results of this study support the results of research by Gangl et al. (2015), Mendoza et al. (2017), Konrad et al. (2016) which provides an empirical evidence that the higher the possibility taxpayers to be audited is, the more obedient the mandatory tax will be voluntarily. The results of this

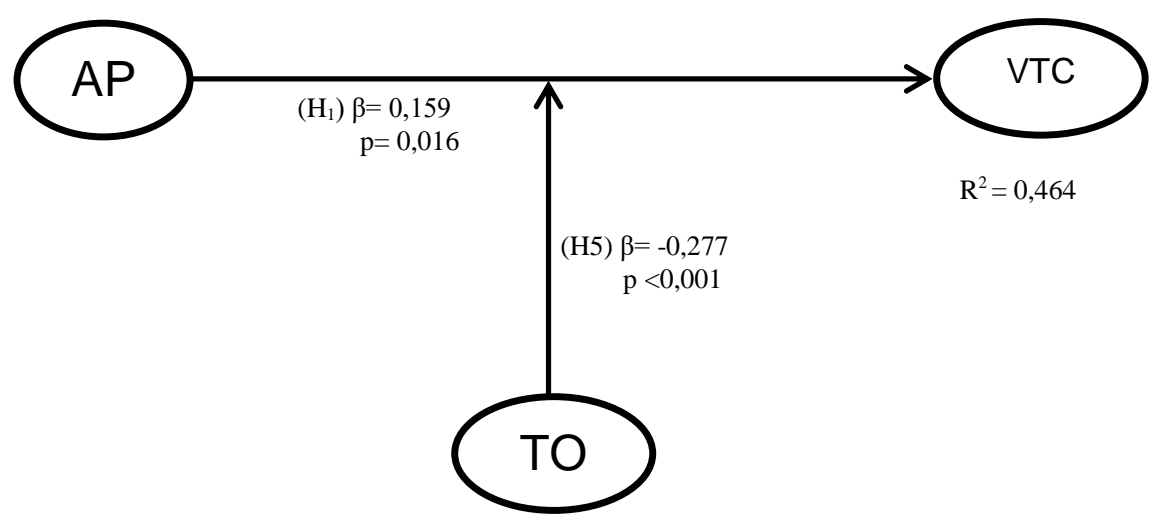

AP = Potential Tax Audit; TO = Tax trust; VTC = Voluntary tax compliance

Figure 1 Research Results 
study are not in line with the research of Oestreich (2017) who did not find empirical evidence regarding the influence of potential tax audits on voluntary tax compliance.

The results of this study support the theory of slippery slope in that tax authorities can use coercive authority to increase voluntary tax compliance. In this study, we explain in great detail about negative coercive authority by using the potential tax audits. Tax authorities can use their authority to conduct tax audit that taxpayers tend to avoid. For taxpayers who have PKP status, they will tend to avoid tax audits because this is also related to their PKP status. According to the Directorate General of Taxation (2013), PKP status of corporate taxpayers could be revoked if fraudulent acts were found during a tax audit and sanctions would be given materially and immaterial. Therefore, when the potential tax audit increases, voluntary tax compliance will increase.

The results of this study also support the theory of bureaucratic reform in that the government's efforts to create a good governance by improving state governance. The goal is to maintain good synergy between tax authorities, taxpayers and the public as can be seen through the potential tax audits conducted by the tax authorities. With the improvement of good integrity and accounting and taxation capabilities of tax authorities, tax audit is increasingly becoming effective and efficient. Such improvement was responded positively by the taxpayers, especially PKP, who saw that if there were financial statements that were deemed not in accordance with regulations by the tax authorities, the potential tax audits would increase so that taxpayers preferred to comply voluntarily. This study shows that the potential tax audits can increase voluntary tax compliance.

\section{Effect of Tax Rewards on Voluntary Tax Compliance}

The results of this study are in line with the research conducted by Bazart and Pickhardt (2011), Brockmann et al. (2016), Fochmann and Kroll (2016) and Göx (2008) who found no empirical evidence related to rewards that affected voluntary tax compliance. Empirical evidence of this study does not support the results of research conducted by Feld, Frey, and Torgler (2006), Lamberton et al. (2013) Mahadianto and Astuti (2017), and Torgler (2003).

The research conducted by Brockmann et al. (2016) was conducted via surrogate, namely students at Jacobs University, Germany. The research by Brockmann et al. (2016) explains that rewards using lottery prize failed to significantly increase tax compliance. Furthermore, they stated that the lottery was tested with the possibility of winning 1:100. The possibility of a small chance to win did not motivate the respondents to increase their voluntary tax compliance. The possibility of this win was also examined by Alm et al. (1992) who succeeded in providing evidence that rewards can improve the tax compliance better than tax audits. But the research of Alm et al. (1992), showed that the probability of winning is $1: 25$. A research conducted by Fochmann and Kroll (2016) describes the effect of rewards with certain criteria. Taxpayers can choose to report their taxes or donate a portion of their income for public interest. The results of the Fochmann and Kroll (2016) study explain that rewards had no effect on large tax compliance. This is because taxpayers will still be compliant even though 
there are no rewards, while for compliance of low tax, the rewards in lottery prize will actually further reduce the level of tax compliance. This is because taxpayers will prefer to pay in the form of contributions for public interest in small amounts so that they do not need to report taxes. Researchers still find small research on the tax rewards made, especially tax rewards in Indonesia. In addition, the characteristics of taxpayers in Indonesia are certainly different those of other countries.

Kepanjen KPP is one of KPPs with larger tax compliance. This is evidenced by the achievements of Kepanjen KPP that achieved the highest tax revenue target in East Java Regional Tax Directorate III. However, this KPP has yet to give rewards in the form of lottery prize to their taxpayers. Even though some KPPs have begun to implement rewards in lottery prize to attract taxpayers to comply as used by KPP Prata ma Purworejo (Editor, 2018). This can be one of the factors in tax rewards that have no effect on voluntary tax compliance.

In relation to the privileges given by the Director General of Taxation as described in PMK No. 74/PMK.03/2012 (Finance, 2012), in order to become a taxpayer with certain criteria, one must meet the stipulated requirements. One of the requirements set in accordance with PMK is to undergo a tax report audit for the last three years. Some taxpayers tend to avoid tax audit mainly because the nature of Indonesian taxpayers who tend to avoid tax audits, while the rewards received were mainly an ease in returning excess tax payments. Such rewards is certainly not worth the effort to go through tax audit. This can also be one factor that rewards do not influence voluntary tax compliance.

\section{Impact of trust in tax authority on the influence of potential tax audit on voluntary tax compliance}

The third hypothesis is to examine the influence of trust in tax authority as a moderating variable in influencing the interaction of potential tax audit of voluntary tax compliance. This study succeeded in providing empirical evidence for the third hypothesis in that trust in tax authority can be a moderating variable significantly to the interaction of potential tax audits with voluntary tax compliance. The coefficient value shows a negative result, meaning that with the existence of trust in tax authority, it decreases the influence between the possibility of tax audits and voluntary tax compliance.

The results of this study explain the influence of tax trust in the theory of slippery slope and in accordance with the arguments of Kirchler et al. (2008) which explained that trust greatly influences voluntary tax compliance and there is an interaction dimension between authority and trust in tax authority. This argument is explained by Gangl et al. (2015) that the dimension of interaction between coercive authority and procedural justice with the intended tax trust is the two variables can influence each other if the relation is a factor that influences voluntary tax compliance.

Trust in tax authority greatly influences voluntary tax compliance (Kirchler et al., 2008). This is evidenced by the results of a study that provides empirical evidence that trust in tax authority has a significant influence on voluntary tax compliance. The coefficient value generated from this study shows a 
positive result. This means that as trust in tax authrotiy increases, the voluntary tax compliance will also increase. However, as a moderating variable, the level of trust in tax authority of taxpayers must also be considered.

In this study, the respondents' answers in answering indicators on tax confidence variable results in average scores. This shows that the taxpayers' trust in Kepanjen KPP tends to be low. The result of this study are also the same as the result of research conducted by Ratmono and Cahyonowati (2013) which stated that trust in tax authority in Indonesia still tends to be low. The low of trust in tax authority may reduce the influence of potential tax audits in increasing voluntary tax compliance.

For voluntary tax compliance, trust plays an important role for the taxpayers and the public to comply to voluntarily tax. The potential tax audit may improve tax compliance only for a certain period of time, but trust in tax authority can increase voluntary tax compliance, whose compliance may be last a longer period of time. The low taxes confidence can decrease the influence of potential inspection on voluntary tax compliance. This is because taxpayers tend to have a lack of trust in tax authorities, so efforts from the tax authorities to increase the potential taxes audit tend to be ignored. Taxpayers do not really care about the potential tax audits because they prioritize to conduct tax evasion neatly so when it is audited it cannot be detected by the tax authority.

\section{Conclusion}

This study aims to analyze factors that influence voluntary tax compliance. Voluntary tax compliance is important to examine because such compliance not only increases tax compliance but can also provide a solution to improve the tax ratio. The variables examined in this study are potential tax audits, rewards and trust in tax authority. This research was conducted on taxpayers with PKP status at Kepanjen KPP in July 2018 with 173 samples.

Results of this study an provide empirical evidence that potential effective and efficient tax audits may increase voluntary tax compliance. Result of this study provides support to theory of slippery slope and heuristic fairness theory that the authority of tax authority can legitimately increase voluntary tax compliance. In addition, procedural justice is also one of the factors that influence voluntary tax compliance. On the other hand, the researchers have not found empirical evidence that rewards can influence voluntary tax compliance. This may be due to the fact that the research location still does not carry out rewards as an activity used by the authorities to attract taxpayers to comply. Rewards are also not considered as something that significantly influence tax compliance in this study.

Other results show that trust in tax authority can moderate the interaction between the potential tax audit of voluntary tax compliance. Although empirical evidence shows that trust in tax authority negatively influenced these interactions. This can occur if respondents in Kepanjen KPP area had tax beliefs that are still on average so that this can influence the taxpayer's decision to comply voluntarily. Implications of results of this study support 
the theory of slippery slope, and heuristic fairness theory which explains that there is a dynamic interaction between trust in tax authority and the authority of tax authority that affects voluntary tax compliance.

Implications of the study provides an empirical evidence related with the importance of trust in tax authority and the potential tax audit to improve tax compliance voluntarily. This serves as an input to tax authorities in KPP Kepanjen and the Government that the tax authorities carry the duty to improve the confidence in taxes and voluntary tax compliance so that it can help the government improve tax compliance voluntary and the tax ratio for long period of time. This can also provide a solution for the government to reach the target of $20 \%$ tax ratio by 2020 by increasing voluntary tax compliance.

\section{References}

Albrow, M. (1970). Bureaucracy (Key Concepts in Political Science) (1970th Edi). Retrieved from https://www.amazon.com/Bureaucracy-KeyConcepts-Political-

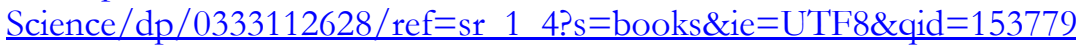
$4217 \& s r=1-$ \&dpID=41RoTYZx $\% 252 B v L \& p r e S T=S Y 291 \quad B O 1,204,203,200$ QL4 0 \&dpSrc $=$ srch

Alm, J., McClelland, G. H., \& Schulze, W. D. (1992). Why do people pay taxes?. Journal of public Economics, 48(1), 21 38.https://doi.org/10.1016/0047-2727(92)90040-M

Bazart, C., \& Pickhardt, M. (2011). Fighting income tax evasion with positive rewards. Public Finance Review, 39(1), 124-149. https://doi.org/10.1177/1091142110381639

Brockmann, H., Genschel, P., \& Seelkopf, L. (2016). Happy taxation: Increasing tax compliance through positive rewards?. Journal of Public Policy, 36(3), 381-406. https://doi.org/10.1017/S0143814X15000331

Budiaji, W. (2013). LIKERT (The Measurement Scale and The Number of Responses in Likert Scale ). Jurnal Ilmu Pertanian Dan Perikanan, 2(2), 127 133. Retrieved from http://www.budiaji.info/publications/skalalikert.pdf

Feld, L. P., Frey, B. S., \& Torgler, B. (2006). Rewarding honest taxpayers? Evidence on the impact of rewards from field experiments. Center for Research in Economics, Management and the Arts (CREMA) Working Paper, 16. Retrieved from www.webmail.crema-research.ch/papers/2006-16.pdf

Fochmann, M., \& Kroll, E. B. (2016). The effects of rewards on tax compliance decisions. Journal of Economic Psychology, 52, 38-55.

https://doi.org/10.1016/i.joep.2015.09.009

Gangl, K., Hofmann, E., \& Kirchler, E. (2015). New Ideas in Psychology Tax authorities 'interaction with taxpayers : A conception of compliance in social dilemmas by power and trust. New Ideas in Psychology, 37, 13-23. https://doi.org/10.1016/i.newideapsych.2014.12.001

Göx, R. F. (2008). Tax incentives for inefficient executive pay and reward for luck. Review of Accounting Studies, 13(4), 452-478. https://doi.org/10.1007/s11142-007-9057-9

Hair, J., Hult, G. T., Ringle, C., \& Sarstedt, M. (2016). A primer on partial least squares structural equation modeling (PLS-SEM). Faculty Bookshelf. https://doi.org/10.1007/978-3-319-05542-8 15-1 
Kastlunger, B., Lozza, E., Kirchler, E., \& Schabmann, A. (2013). Powerful authorities and trusting citizens: The Slippery Slope Framework and tax compliance in Italy. Journal of Economic Psychology, 34, 36-45. https://doi.org/10.1016/i.joep.2012.11.007

Kirchler, E., Hoelzl, E., \& Wahl, I. (2008). Enforced versus voluntary tax compliance: The "slippery slope" framework. Journal of Economic Psychology, 29(2), 210-225. https://doi.org/10.1016/i.joep.2007.05.004

Kock, N. (2015). One-tailed or two-tailed P values in PLS-SEM?. International Journal of $e$-Collaboration (IJeC), 11(2), 1-7. https://doi.org/10.4018/ijec.2015040101

Konrad, K. A., Lohse, T., \& Qari, S. (2016). Compliance with endogenous audit probabilities. The Scandinavian Journal of Economics, 119(3), 1-32. https://doi.org/10.1111/ipet.12038

Lamberton, C. P., De Neve, J., \& Norton, M. I. (2013). Eliciting Taxpayer Preferences Increases Tax Compliance. Ssrn. https://doi.org/10.2139/ssrn.2365751

Mahadianto, M. Y., \& Astuti, A. D. (2017). Previllage tax payer, sosialisasi pajak dan kepercayaan pada otoritas pajak terhadap kepatuhan. Jurnal Kajian Akuntansi, 1(1), 77-86. Retrieved from http://jurnal.unswagati.ac.id/index.php/ika/article/viewFile/525/379

Mendoza, J. P., Wielhouwer, J. L., \& Kirchler, E. (2017). The backfiring effect of auditing on tax compliance. Journal of Economic Psychology, 62, 284-294. https://doi.org/10.1016/i.joep.2017.07.007

Oestreich, A. M. (2017). On optimal audit mechanisms for environmental taxes. Journal of Environmental Economics and Management, 84, 62-83. https://doi.org/10.1016/i.jeem.2017.02.005

Puspita, A. F., Subroto, B., \& Baridwan, Z. (2016). The analysis of individual behaviour of corporate taxpayers' obedience: Tax compliance model (study of hotels in Malang and Batu). Review of Integrative Business and Economics Research, 5(3), 135-160.

Ratmono, D., \& Cahyonowati, N. (2013). Kepercayaan terhadap otoritas pajak sebagai pemoderasi pengaruh deterrence factor terhadap kepatuhan wajib pajak pribadi. Jurnal Akuntansi Indonesia, 2(1), 27-36. Retrieved from http://jurnal.unissula.ac.id/index.php/jai/article/view/854

Sedarmayanti. (2010). Manajemen Sumber Daya Manusia:Reformasi Birokrasi dan Manajemen Pegawai Negeri Sipil. Bandung: Refika Aditama. Retrieved from https://www.belbuk.com/manajemen-sumber-dayamanusia-reformasi-birokrasi-dan-manajemen-pegawai-negeri-sipil-p$\underline{16245 . h t m l}$

Sekaran, \& Bougie. (2013). Research Methods For Business: A Skill-Building Approach. Wiley. https://doi.org/http://as.wiley.com/WileyCDA/WileyTitle/productCd111994225X.html\#

Slemrod, J., Blumenthal, M., \& Christian, C. (2001). Taxpayer response to an increased probability of audit: Evidence from a controlled experiment in Minnesota. Journal of Public Economics, 79(3), 455-483. https://doi.org/10.1016/S0047-2727(99)00107-3

Sugiono. (2004). Konsep, Identifikasi, Alat Analisis Dan Masalah Penggunaan Variabel Moderator. Jurnal Studi Manajemen \& Organisasi, 1(2), 61-70. Retrieved from https://ejournal.undip.ac.id/index.php/smo/article/viewFile/4175/382 $\underline{2}$

Torgler, B. (2003). Beyond Punishment: A Tax Compliance Experiment with Taxpayers in Costa Rica. Revista de Análisis Económico. https://doi.org/10.4324/9780203851616 
Tyler, T. R. (2006). Psychological Perspectives on Legitimacy and Legitimation. Annual Review of Psychology, 57(1), 375-400. https://doi.org/10.1146/annurev.psych.57.102904.190038

Tyler, T. R. (2010). Legitimacy in corrections. Criminology \& Public Policy, 9(1), 127-134. https://doi.org/10.1111/i.1745-9133.2010.00615.x

\section{Regulation:}

Direktorat Jenderal Pajak. (2015). Laporan Tahunan Direktorat Jenderal Pajak 2015.

Direktorat Jenderal Pajak. (2016). Laporan Kinerja Direktur Jenderal Pajak 2016.

Direktorat Jenderal Pajak, K. K. R. I. (2013). Undang-Undang PPh dan Peraturan Pelaksanaannya.

Kementerian Keuangan. (2012). Tata Cara Penetapan Dan Pencabutan Penetapan Wajib Pajak Dengan Kriteria Tertentu Dalam Rangka Pengembalian Pendahuluan Kelebihan Pembayaran Pajak - PMK No. 74/PMK.03/2012. Retrieved from http://ketentuan.pajak.go.id/index.php? $\mathrm{r}=$ aturan/rinci\&idcrypt $={ }_{\mathrm{O}} \mathrm{JinoK}$ $\underline{\mathrm{I} \% 3 \mathrm{D}}$

Kementrian Badan Usaha Milik Negara (2002). Keputusan Menteri Badan Usaha Milik Negara Nomor: Kep-102 / Mbu / 2002 Tentang Badan Usaha Milik Negara Menteri Badan Usaha Milik Negara ,. Peraturan Pemerintah. Retrieved from http://jdih.bumn.go.id/baca/KEP-117/MMBU/2002.pdf

\section{Website:}

OECD. (2016). Revenue Statistics 2017: Tax revenue trends in the OECD. Retrieved from www.oecd.org/tax/tax-policy/revenuestatistics.htm $\% 0$ AFurther

Redaksi. (2018). KPP Pratama Purworejo Bagi-bagi Hadiah kepada WP yang Lapor Awal Waktu. Purworejo News. Retrieved from http://purworejonews.com/berita/kpp-pratama-purworejo-bagi-bagihadiah-kepada-wp-yang-lapor-awal-waktu/

World Bank. (2015). Paying Taxes 2015: The global picture. The changing face of tax compliance in 189 economies worldwide. Retrieved from www.pwc.com/gx/en/services/tax/paying-taxes.html

World Bank. (2016). Paying Taxes 2016. Retrieved from www.pwc.com/gx/en/services/tax/paying-taxes.html

World Bank. (2017). Paying Taxes 2017. Retrieved from www.pwc.com/gx/en/services/tax/paying-taxes.html 